\title{
Depression and anxiety disorder in hyperemesis gravidarum: A prospective case-control study
}

\section{Hiperemezis gravidarumlu kadinlarda depresyon ve anksiyete bozukluğu: Prospektif olgu kontrol çalışması}

\author{
Yusuf Topalahmetoğlu, Mehmet Metin Altay, Derya Akdağ Cırık, Yusuf Aytaç Tohma, Eser Çolak, \\ Bora Çoşkun, Orhan Gelişen \\ University of Health Sciences, Etlik Zübeyde Hanım Women's Health Training and Research Hospital, Clinic of Obstetrics and Gynecology, Ankara, Turkey
}

\begin{abstract}
Objective: To assess the anxiety and depression status of women with hyperemesis gravidarum (HG); the risk factors for developing both depression and anxiety in women with HG were evaluated.

Materials and Methods: A total of 200 women, 100 diagnosed as having HG before the 20th week of gestation at a tertiary referral center and 100 gestational-age-matched controls were enrolled. The socio-demographic data and the depression and anxiety scores, as assessed using the Beck depression and anxiety inventory were compared between the two groups.

Results: The median depression and anxiety scores were significantly higher in the HG group compared with controls (19.5 vs. 9.0 and 22.0 vs. 10.0). Women with HG have the highest relative risks for moderate depression and severe anxiety [relative risk (RR): 16.88 and RR: 20.50, respectively]. In the univariate analysis, having HG, low education level, low income and poor social relationships were significant predictors of depression and having HG. Moreover, poor social relationships significantly predicted the presence of anxiety disorder. However, having HG and poor social relationships were found as the only independent predictors of both depression and anxiety. Patients with HG were 5.5 and 6.7 times more prone to having depression and anxiety disorder compared with controls, respectively.

Conclusion: Both depression and anxiety disorder were more frequent in women with HG who have weak family and social relationships, lower education and income levels. Therefore, the determination of the psychological status of women with HG should be an integral part of the evaluation.

Keywords: Hyperemesis gravidarum, pregnancy, depression, anxiety disorder

Öz

Amaç: Araştırmanın birincil amacı, hiperemezis gravidarum (HG) olan kadınların anksiyete ve depresyon durumlarını değerlendirmektir. Ayrıca, tüm gruptaki depresyon ve anksiyete için risk faktörlerini de değerlendirdik.

Gereç ve Yöntemler: Gebeliğin 20. haftasından önce üçüncü basamak bir merkezde HG teşhisi konan 100 kadın ve gebelik haftası eşleştirilen 100 kontrol olmak üzere toplam 200 kadın çalışmaya dahil edildi. Sosyo-demografik veriler ve Beck depresyon ve anksiyete envanteri ile değerlendirilen depresyon ve anksiyete skorları iki grup arasında karşılaştırıldı.

Bulgular: Medyan depresyon ve anksiyete skorları HG grubunda kontrol grubuna göre anlamlı derecede yüksekti (sırasıyla 19,5 ve 9,0 ve 22,0 ve 10,0). Orta sınıf depresyon ve şiddetli kaygı açısından HG'li kadınlar en yüksek relatif riske sahipti [relatif risk (RR): 16,88 ve RR: 20,50]. Tek değişkenli analizde; düşük eğitim düzeyi, düşük gelir ve zaylf sosyal ilişkiler depresyon ve HG'ye sahip olma yönündeki prediktif belirteçlerdir, zayıf sosyal ilişkiler anksiyete bozukluğunu önemli ölçüde öngörmüştür. Bununla birlikte, çok değişkenli analiz sonrası depresyon ve anksiyete bozukluğunun bağımsız öngördürücüleri olarak sadece HG ve zayıf sosyal ilişkiler bulunmuştur. HG hastalarının, kontrol grubuna göre depresyon ve anksiyete bozukluklarına sırasıyla 5,5 ve 6,7 kat daha fazla eğilimli olduğu bulundu.

Sonuç: Depresyon ve anksiyete bozukluğunun her ikisi de HG'li, zayıf aile ve sosyal ilişki, düşük eğitim ve düşük gelirli kadınlarda görülmüştür. Bu nedenle, özellikle düşük sosyo-ekonomik popülasyonlar için, hastaların psikolojik durumu, HG değerlendirmesinin vazgeçilmez bir parçası olmalıdır.

Anahtar Kelimeler: Hiperemezis gravidarum, gebelik, depresyon, anksiyete bozukluğu
\end{abstract}

PRECIS: We showed that having weak family and social relationships, lower socio-economic status played an important role in the development of depression and anxiety in pregnant women.

Address for Correspondence/Yazışma Adresi: Derya Akdağ Cırık, MD,

University of Health Sciences, Etlik Zübeyde Hanım Women's Health Training and Research Hospital, Clinic of Obstetrics and Gynecology, Ankara, Turkey

Phone: +90 5066288930 E-mail: deryaakdag@yahoo.com ORCID ID: orcid.org/0000-0003-0302-051X

Received/Geliș Tarihi: 19.06.2017 Accepted/Kabul Tarihi: 20.10.2017

${ }^{\oplus}$ Copyright 2017 by Turkish Society of Obstetrics and Gynecology

Turkish Journal of Obstetrics and Gynecology published by Galenos Publishing House. 


\section{Introduction}

Nausea and vomiting during early pregnancy is very common and generally accepted as a part of normal physiology $y^{(1,2)}$. Hyperemesis gravidarum (HG) is a pregnancy condition characterized by severe nausea and vomiting starting before the $22^{\text {nd }}$ week of gestation. Although it generally ends before the $16^{\text {th }}$ week, HG may be severe in $2 \%$ of pregnant women, who require hospitalization ${ }^{(1,2)}$. Although there is no universally accepted criteria for the diagnosis, HG is characterized by persistent vomiting and nausea, weight loss of more than $5 \%$ of pre-pregnancy body weight, ketonuria, electrolyte abnormalities (hypokalemia), and dehydration (high urine specific gravity), resulting in the diminishment of the woman's quality of life and a significant contribution to health care costs and time lost from work due to persistent vomiting ${ }^{(3)}$. Despite its frequency, the etiopathogenesis of HG has not yet been clearly elucidated. Many theories based on endocrinologic and metabolic factors, gastrointestinal dysfunction, and immunologic, genetic, and psychological factors have been proposed ${ }^{(2-4)}$. Besides its physical symptoms such as dehydration and electrolyte imbalance, HG can also affect quality of life and the psychological state of pregnant women ${ }^{(5,6)}$.

Depression is the most common psychological disease seen in women, and encountered in 14\% to $48 \%$ of pregnant women ${ }^{(7-10)}$. Although recent studies demonstrated higher rates of depression and anxiety in pregnant women with $H G$, few studies have evaluated the predictive factors or cause-and-effect relation of these psychological disorders and pregnancy ${ }^{(11-15)}$.

In this case-control study, the anxiety and depression disorder of pregnant women with HG was assessed, and we aimed to determine the risk factors for developing both depression and anxiety in pregnant women.

\section{Materials and Methods}

The study was conducted in a tertiary care center, Etlik Zübeyde Hanım Women's Health Training and Research Hospital from June 2013 to October 2013. The local ethics committee approved the study (approval number: 2013-165) and all participants gave written informed consent. The trial was performed in accordance with the Declaration of Helsinki. Pregnant women diagnosed as having HG before the $20^{\text {th }}$ week of the current viable pregnancy and required hospitalization for intravenous fluid replacement were included in the study group. Persistent vomiting accompanied by weight loss exceeding 5\% of pre-pregnancy body weight, an objective measure of acute starvation (usually large ketonuria on urine analysis), electrolyte abnormalities and acid-base disturbances, was diagnosed as HG. Gestational-age-matched controls were recruited from patients who came for routine antenatal care follow-ups. Patients who had multiple pregnancies, thyroid disease, prior psychiatric disease or conditions with elevated serum human chorionic gonadotropin levels such as gestational trophoblastic diseases and chromosomally abnormal fetus were excluded.
All participants were asked to complete a demographic and socioeconomic data collection form. In this form, patients assessed and rated their relations with other family members and society as strong or weak.

\section{Anxiety and depression scores}

The status of depression and anxiety was evaluated using the Beck Depression Inventory (BDI)-II and Beck Anxiety Inventory (BAI). The BDI includes a 21-question selfassessment scale and answers were scored from 0 to 3. BDI scores were grouped as follows: 0-9 as no depression, 10-16 as mild depression, 17-23 as moderate depression, and 24-63 as severe depression. Answers to each question in the BAI were scored from 0 to 3. The BAI scores were classified as follows: 0-7 as no anxiety, 8-15 as mild anxiety, 16-25 as moderate anxiety, and 24-63 as severe anxiety.

\section{Statistical Analysis}

Statistical analysis was performed using SPSS 21.0 (IBM Corp. Released 2012. IBM SPSS Statistics for Windows, Version 21.0. Armonk, NY). Univariate analyses to identify variables associated with anxiety and depression were investigated using appropriate statistical tests such as Student's t-test, the chi-square test and Mann-Whitney U tests. The Kruskal-Wallis test was used to compare the anxiety and depression scores between the two groups in terms of different variables. Bonferroni correction was used to test the significance with pairwise differences to adjust multiple comparisons. The association between ordinal variables was investigated, and correlation significance was calculated using the Spearman test. For multivariate analyses, possible factors identified were further entered into the logistic regression analysis to determine the independent predictors of anxiety and depression. A 5\% type 1 error was used for the statistical significance.

\section{Results}

A total of 100 pregnant women with HG and 100 gestationalage-matched controls were included in the study. The sociodemographic data of all participants are listed in Table 1. Using BDI, the median depression scores were significantly higher in the HG group compared with controls (19.5 vs. 9.0; $\mathrm{p}<0.001)$. Similarly, using BAI, the median anxiety scores were also higher in the HG group compared with controls (22.0 vs. 10.0; $\mathrm{p}<0.001)$. The percentage of pregnant women living on minimum wage was nearly double in the HG group compared with controls (61.9\% vs. $38.0 \%$; $\mathrm{p}=0.01$ ). The education level was also significantly lower in the HG group compared with controls such that the percentage of women who graduated from at least high school among the HG and control groups were $40.4 \%$ and $59.6 \%$, respectively ( $p=0.005$ ). Pregnant women who defined their relationship with their families as "weak" had a higher percentage of HG than those who defined them as "strong" (69\% vs. 31.0\%; $\mathrm{p}=0.027$ ). Similarly, women who had weak social relations 
were also more prone to having HG (63.6\% vs. $36.4 \%$ $\mathrm{p}=0.041$ ).

When all other possible contributing factors were matched, patients in the HG group had a higher risk of having depression or anxiety (mild, moderate or severe) compared with controls (Table 2). The relative risk of women with HG was highest for moderate depression and severe anxiety (16.88 vs. 20.50).

Data of all participants were analyzed to determine the risk factors for depression and anxiety. HG, lower educational status, lower income, and poor social relationships were the significant risk factors for depression and HG, and poor social relationships was a significant risk factor for anxiety in the entire pregnant population (Table 3). Additionally, HG and poor social relationships were independent risk factors for both depression and anxiety in the entire cohort. Patients with HG were 5.5 times more prone to having depression and 6.7 times more prone to having anxiety compared with the matched controls. Additionally, risks of having depression and anxiety in pregnant women with poor social relationships were 2.8 and 5.6 times higher, respectively, when compared with controls (Table 4).

\section{Discussion}

The psychological theory for describing the pathogenesis of HG suggests that either the presence of conversion or somatization disorder, or the exaggerated response of a patient to stress may cause $H G^{(16)}$. Although nausea and vomiting during pregnancy were more commonly seen in dependent, hysterical, depressive, and anxious women, severe and persistent vomiting itself might also cause the psychological problems in patients ${ }^{(17-22)}$.

Table 1. Socio-demographic characteristics of the hyperemesis and control group

\begin{tabular}{|c|c|c|c|}
\hline & $\mathrm{HG}^{1}(\mathrm{n}=100)$ & Control $(\mathrm{n}=100)$ & $\mathrm{p}$ value \\
\hline Age (years) & $26.0(9.0)$ & $25.0(6.0)$ & 0.254 \\
\hline Age at marriage (years) & $21.0(4.0)$ & $20.0(4.0)$ & 0.741 \\
\hline Gravidity & $2.0(2.0)$ & $2.0(2.0)$ & 0.859 \\
\hline Parity & $1.0(1.0)$ & $1.0(1.0)$ & 0.775 \\
\hline Paid employment & $21(21 \%)$ & $16(16 \%)$ & 0.363 \\
\hline Low income ${ }^{2}$ & $60(60 \%)$ & $37(37 \%)$ & 0.001 \\
\hline High school graduate & $42(42 \%)$ & $62(62 \%)$ & 0.005 \\
\hline Poor relationships & $20(20 \%)$ & $9(9 \%)$ & 0.027 \\
\hline Poor social relationships & $28(28 \%)$ & $16(16 \%)$ & 0.041 \\
\hline Depression score & $19.5(11.0)$ & $9.0(8.8)$ & $<0.001$ \\
\hline Anxiety score & $22.0(14.5)$ & $10.0(11.8)$ & $<0.001$ \\
\hline $\begin{array}{l}\text { Data presented as median (interquartile) and number (percentage) } \\
{ }^{1} \mathrm{HG} \text { : Hyperemesis gravidarum } \\
{ }^{2} \text { Monthly income of less than } 1070 \text { Turkish Liras (approximately USD 480) }\end{array}$ & & & \\
\hline
\end{tabular}

Table 2a. The relative risk of depression (a) or anxiety (b) in the hyperemesis and control groups

\begin{tabular}{llll}
\hline $\mathrm{HG} \mid$ control $^{1}$ & Odds ratio & $95 \% \mathrm{CI}^{2}$ Min; Max & $\mathrm{p}$ value \\
\hline Mild depression & 2.53 & $1.14 ; 5.60$ & 0.022 \\
Moderate depression & 16.88 & $7.18 ; 39.66$ & $<0.001$ \\
Severe depression & 3.86 & $1.21 ; 12.28$ & 0.022 \\
${ }^{1}$ Hyperemesis gravidarum group compared to controls, ${ }^{2}$ Confidence interval & & \\
HG: Hyperemesis gravidarum, Min-Max: Minimum-Maximum, CI: Confidence interval & &
\end{tabular}

Table $2 \mathrm{~b}$. The relative risk of anxiety (b) in the hyperemesis and control groups

\begin{tabular}{llll}
\hline $\mathrm{HG}^{1} \mid$ control & Odds ratio & $95 \% \mathrm{CI}^{2} \mathbf{M i n}$; Max & $\mathrm{p}$ value \\
Mild anxiety & 2.62 & $1.05 ; 6.56$ & 0.039 \\
Moderate anxiety & 9.11 & $3.64 ; 22.79$ & $<0.001$ \\
Severe anxiety & 20.50 & $7.16 ; 58.72$ & $<0.001$ \\
${ }^{1}$ Hyperemesis gravidarum group compared to controls, ${ }^{2}$ Confidence interval & & \\
HG: Hyperemesis gravidarum, Min-Max: Minimum-Maximum, CI: Confidence interval & &
\end{tabular}


In this study, we investigated the possible effects of many sociodemographic parameters on HG. Among these parameters, some (age, parity, previous miscarriage, age of marriage and working status) were found not to be related, whereas others (income level, education level, social and family relations) were found related. Anxiety and depression were significantly more common and more severe in the HG group than in the controls. Similar to Hizli et al. ${ }^{(15)}$, we also found the incidence of depression as

Table 3. Parameters tested to be risk factors for depression or anxiety in early pregnancy: univariate analysis

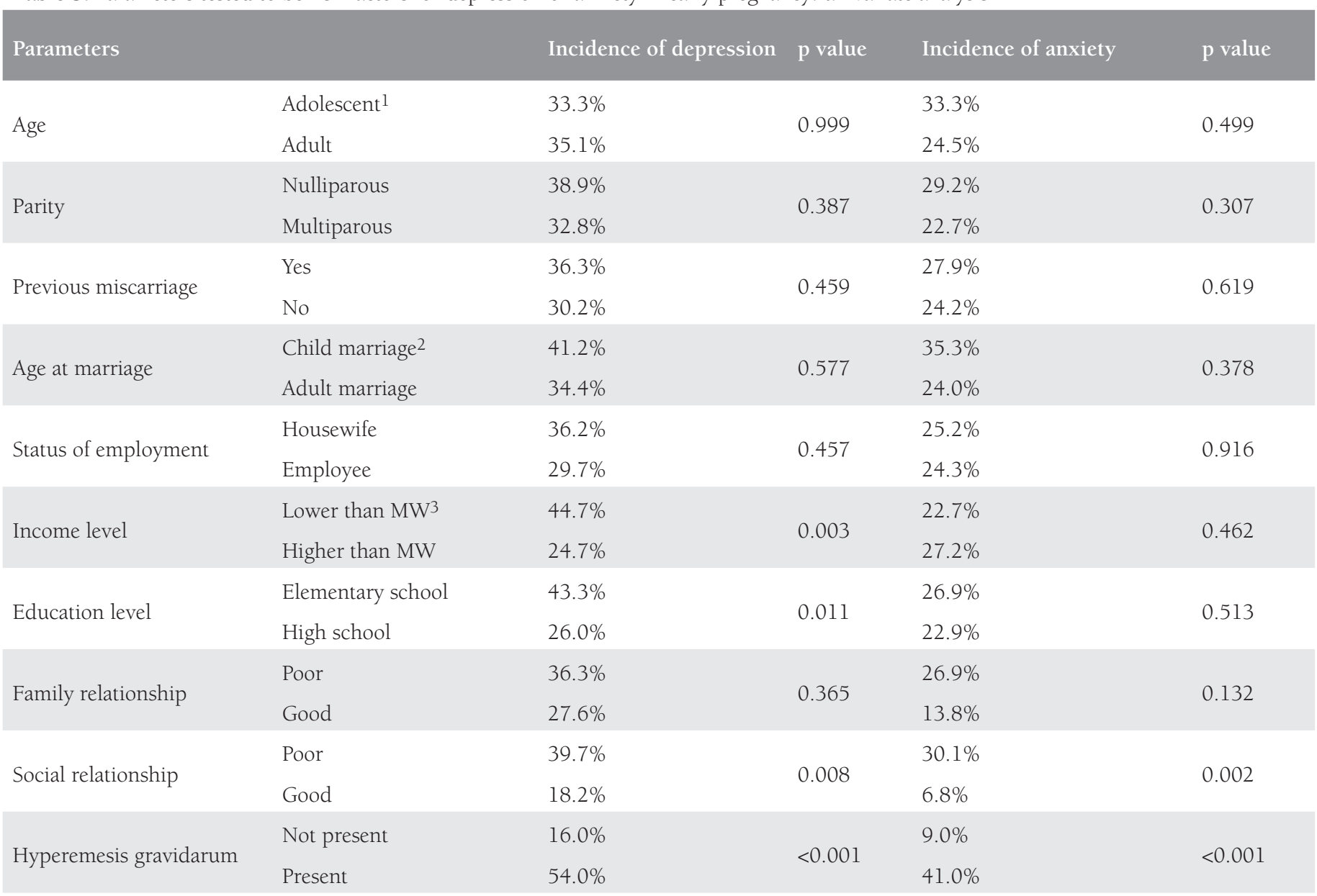

${ }^{1}$ Patient $\geq 19$ years of age, ${ }^{2}$ Formal marriage or informal union before age 18 years

MW3: Minimal wage

Table 4. Relative risk ratios of various parameters for depression and anxiety: multivariate analysis

\begin{tabular}{|c|c|c|c|}
\hline & ${ }^{1} \mathbf{R R}$ & 295\% CI (upper-lower) & $\mathrm{p}$ value \\
\hline \multicolumn{4}{|l|}{ Risk factors for depression } \\
\hline Low income & 1.615 & $0.800-3.258$ & 0.181 \\
\hline Lower education & 1.361 & $0.673-2.752$ & 0.390 \\
\hline Poor family relationship & 1.934 & $0.637-5.869$ & 0.244 \\
\hline Poor social relationship & 2.842 & $1.037-7.791$ & 0.042 \\
\hline HG & 5.505 & $2.755-10.998$ & $<0.001$ \\
\hline \multicolumn{4}{|c|}{ Risk factors for anxiety disorder } \\
\hline Poor social relationship & 5.689 & $1.449-22.340$ & 0.013 \\
\hline Poor family relationship & 1.351 & $0.354-5.164$ & 0.660 \\
\hline HG & 6.704 & $2.974-15.111$ & $<0.001$ \\
\hline
\end{tabular}

${ }^{1}$ Predictive relative risk calculated with odds ratio, ${ }^{295 \%}$ CI: Confidence interval, RR: Relative risk, HG: Hyperemesis gravidarum 
84\% in the HG group. This high incidence of depression might be attributed to the completion of questionnaires on the first day of hospitalization and high percentage of patients with low income. In the univariate analysis, patients with low income, low educational status, and poor social relationships had increased risk for having depression in the current study. An alternative view is that $\mathrm{HG}$ is an independent variable that increases the relative risk of all stages of anxiety and depression. The most dramatic effect of HG was seen on the development of severe anxiety. A woman with HG was 20.5 times more prone to having severe anxiety compared with healthy pregnant woman in the present study. These findings are consistent with some previous studies; however; some other studies could not demonstrate an association between severity of HG and depression ${ }^{(19-21)}$.

Predictive factors for developing anxiety disorder and depression in pregnant women with HG were also investigated in a few studies $^{(11,14,17)}$. Tan et al. ${ }^{(14)}$ investigated the incidence and risk factors for developing anxiety and depression in a cohort of 209 women with HG in early pregnancy. HG was found to be the only independent risk factor for developing anxiety, and the only independent protective factor for developing depression was the history of miscarriage. In 2012, Hizli et al.(15) evaluated the impact of HG and socio-demographic variables on depression in Turkish patients during pregnancy. They used the BDI-II and reported the incidence of depression as $80 \%$ in the HG group and $5 \%$ in the control group. They also stated that the presence of HG was the most important predictor of depression, and additionally, young maternal age and poor family interaction were other weaker contributors. Recently, Annagür et al. ${ }^{(11)}$ investigated the association between HG and eating attitudes on anxiety and depression symptoms in 48 women with HG and 44 controls. The authors concluded that HG was associated with symptoms of anxiety and depression but not with eating attitudes.

\section{Study Limitations}

The strengths of the study are the use of objective inclusion criteria and a relatively high number of patients, and the limitations are the use of psychiatrics test for depression instead of examinations by a psychiatrist, and the matching process between the study and control group was insufficient.

\section{Conclusion}

In this study, we showed that both depression and anxiety disorders were more common and severe in patients with HG compared with controls. In addition, having weak family and social relationships and lower socioeconomic status also played an important role in developing depression and anxiety in pregnant women. Therefore, the psychological state of patients should also be noticed during the evaluation for physical health of women with HG.

\section{Ethics}

Ethics Committee Approval: The study was approved by Etlik Zübeyde Hanım Women's Health Teaching and Research
Hospital Ethics Committee (approval number and date: 2013165/27.05.2013).

Informed Consent: A consent form was completed by all participants.

Peer-review: External and internal peer-reviewed.

\section{Authorship Contributions}

Surgical and Medical Practices: Y.T., B.Ç., E.Ç., Concept: M.M.A., Y.A.T., Design: Y.T., D.A.C., O.G., Data Collection or Processing: Y.T., E.Ç., Y.A.T., Analysis or Interpretation: D.A.C., M.M.A., O.G., Literature Search: B.Ç., E.Ç., Writing: Y.T., D.A.C, Y.A.T.

Conflict of Interest: No conflict of interest was declared by the authors.

Financial Disclosure: The authors declared that this study received no financial support.

\section{References}

1. Gazmararian JA, Petersen R, Jamieson DJ, Schild L, Adams MM, Deshpande $\mathrm{AD}$, et al. Hospitalizations during pregnancy among managed care enrollees. Obstet Gynecol 2002;100:94-100.

2. London V, Grube S, Sherer DM, Abulafia O. Hyperemesis Gravidarum: A Review of Recent Literature. Pharmacology 2017;100:161-71.

3. Yeh CC, Tsui KH, Wang PH. Hyperemesis Gravidarum. J Chin Med Assoc 2017.

4. Munch S, Korst LM, Hernandez GD, Romero R, Goodwin TM. Health-related quality of life in women with nausea and vomiting of pregnancy: the importance of psychosocial context. J Perinatol 2011;31:10-20.

5. Masson GM, Anthony F, Chau E. Serum chorionic gonadotrophin, schwangerschafts protein 1, progesterone and estradiol levels in patients with nausea and vomiting in early pregnancy. Br J Obstet Gynaecol 1985;92:211-5.

6. Walsh JW, Hasler WL, Nugent CE, Owyang C. Progesterone and estrogen are potential mediators of gastric slow-wave dysrhythmias in nausea of pregnancy. Am J Physiol 1996;270:506-14.

7. Shiah YJ, Chang F, Chiang SK, Lin IM, Tam WC. Religion and health: anxiety, religiosity, meaning of life and mental health. J Relig Health 2015;54:35-45.

8. Koch KL, Stern RM, Vasey M, Botti JJ, Creasy GW, Dwyer A. Gastric dysrhythmias and nausea of pregnancy. Dig Dis Sci 1990;35:961-8.

9. Deal LW, Holt VL. Young maternal age and depressive symptoms: results from the 1988 National Maternal and Infant Health Survey. Am J Public Health 1998;88:266-70.

10. Orr ST, James SA, Blackmore Prince C. Maternal prenatal depressive symptoms and spontaneous preterm births among African-American women in Baltimore, Maryland. Am J Epidemiol 2002;156:797-802.

11. Annagür BB, Kerimoğlu ÖS, Gündüz Ş, Tazegül A. Are there any differences in psychiatric symptoms and eating attitudes between pregnant women with hyperemesis gravidarum and healthy pregnant women? J Obstet Gynaecol Res 2014;40:1009-14.

12. Uguz F, Gezginc K, Kayhan F, Cicek E, Kantarci AH. Is hyperemesis gravidarum associated with mood, anxiety and personality disorders: a case-control study. Gen Hosp Psychiatry 2012;34:398-402.

13. Tan PC, Zaidi SN, Azmi N, Omar SZ, Khong SY. Depression, anxiety, stress and hyperemesis gravidarum: temporal and case controlled correlates. PLoS One 2014;17;9:e92036.

14. Tan PC, Vani S, Lim BK, Omar SZ. Anxiety and depression in hyperemesis gravidarum: prevalence, risk factors and correlation with clinical severity. Eur J Obstet Gynecol Reprod Biol 2010;149:153-8. 
15. Hizli D, Kamalak Z, Kosus A, Kosus N, Akkurt G. Hyperemesis gravidarum and depression in pregnancy: is there an association? J Psychosom Obstetr Gynaecol 2012;33:171-5.

16. Buckwalter JG, Simpson SW. Psychological factors in the etiology and treatment of severe nausea and vomiting in pregnancy. Am J Obstet Gynecol 2002;186(Suppl 5):210-4.

17. Iancu I, Kotler M, Spivak B, Radwan M, Weizman A. Psychiatric aspects of hyperemesis gravidarum. Psychother Psychosom 1994;61:143-9.

18. Simpson SW, Goodwin TM, Robins SB, Rizzo AA, Howes RA, Buckwalter DK, et al. (2001) Psychologic factors and hyperemesis gravidarum. J Womens Health Gend Based Med 2001;10:471-7.
19. Köken G, Yilmazer M, Cosar E, Sahin FK, Cevrioglu S, Gecici O. Nausea and vomiting in early pregnancy: relationship with anxiety and depression. J Psychosom Obstetr Gynaecol 2008;29:91-5.

20. Kjeldgaard HK, Eberhard-Gran M, Benth JŠ, Vikanes ÅV. Hyperemesis gravidarum and the risk of emotional distress during and after pregnancy. Arch Womens Ment Health 2017;20:747-56.

21. Bozzo P, Einarson TR, Koren G, Einarson A. Nausea and vomiting of pregnancy (NVP) and depression: cause or effect? Clin Invest Med 2011;34:245.

22. Gadsby R. Pregnancy nausea and vomiting-the role of the midwife. Pract Midwife 2012;15:17-9. 